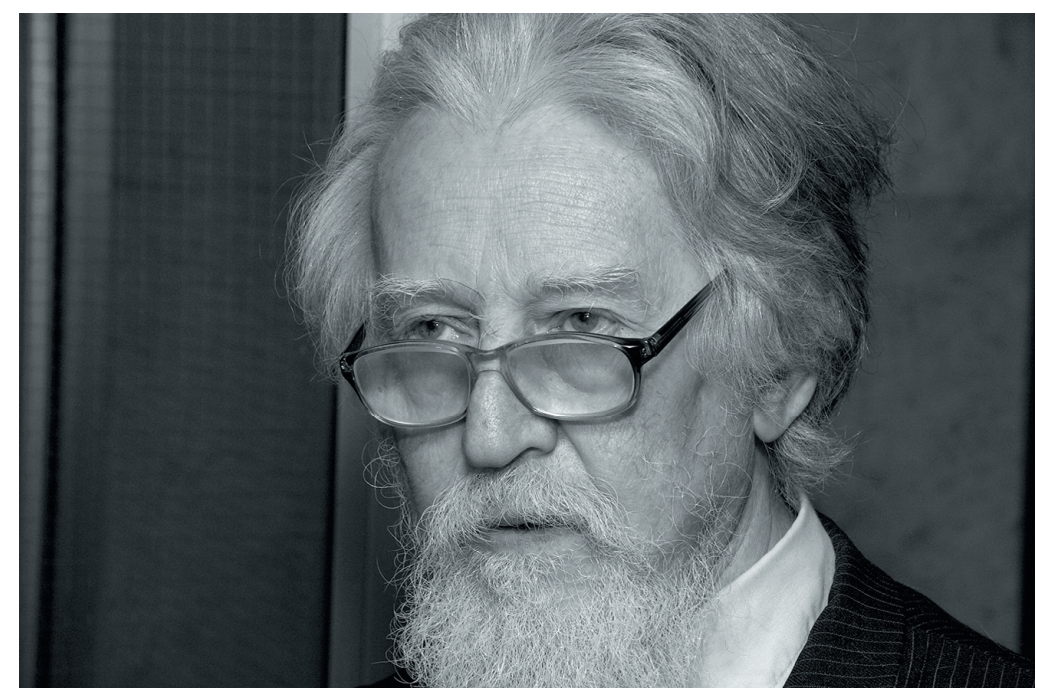

\title{
Владимиру Антоновичу Дыбо 80 пет (30 апреля 2011 г.)
}

В этом году в Москве прошли целых три лингвистических конференции по случаю юбилея В. А. Дыбо. Кроме чисто хронологического значения - а это более чем полувековая веха блестящей научной деятельности крупнейшего учёного, - этот юбилей даёт прекрасную возможность оценить необычайную широту его научных интересов. В своих докладах на этих конференциях коллеги и ученики Владимира Антоновича затронули такие разнообразные темы, как балто-славянская, индоевропейская и уральская акцентология, глоттохронология, сравнительная тюркология и кавказология, а также другие интересующие В. А. Дыбо области, в большинстве из которых проявил себя его компаративистский гений. Доклады в очередной раз продемонстрировали роль юбиляра в этих научных областях, которые вряд ли достигли бы своего сегодняшнего уровня без его активного и руководящего участия.

Так, именно Владимиру Антоновичу обязана современная акцентология своими важнейшими достижениями. Обрисуем вкратце главные этапы тернистого пути, пройденного этой дисциплиной, пережившей в последние десятилетия беспрецедентный взлёт. Новая эра славянской акцентологии началась с публикации в 1957 г. революционного труда Хр. Станга «Slavonic Accentuation» ${ }^{1}$, который порвал с заблуждениями зашедшей к тому времени в тупик «классической акцентологии» начала XX века. Новый - парадигматический - подход впервые позволял обозреть целостно и систематически весь массив имеющихся данных, до сих пор казавшихся беспорядочными и слабо мотивированными. В числе прочего, Станг доказал генетическое тождество подвижной славянской и литовской акцентных парадигм (а.п. с и а.п. 3), тем самым отрицая правомерность так называемого закона Фортунатова, являвшего собой краеугольный камень «классической акцентологии».

По Стангу, в славянском языке исконно было три акцентных парадигмы $(a, b, c)$, которые восходили к индоевропейской эпохе. Именно в этом и было слабое место его реконструкции. Сразу осознав фундаментальную важность труда Станга, но также изъяны в его концепции, В. А. Дыбо начал большу́ю теоретическую работу, призванную, по его первоначальному замыслу, привести к реабилитации закона Фортунатова в славянском. Однако довольно быстро он обнаружил в системе определённые закономерности, из которых вытекали важные выводы: оказалось, что акцентные парадигмы $a$ и $b$ дополнительно распределены в зависимости от типа корня, что неожиданным образом сводило набор балтославянских акцентных типов до двух парадигм: неподвижной и подвижной ${ }^{2}$ Этому открытию нашлось применение в анализе кельто-

\footnotetext{
${ }^{1}$ STANG, Christian. Slavonic accentuation. Oslo, 1957.

2 В то время подвижность отождествляли с греко-арийской окситонезой, т.е. ударением на окончании, в отличие от баритонезы, соответствовавшей накоренному ударению (неподвижности). Реконструкция балтославянской системы, основанная на 
италийского материала, проведённом В. А. Дыбо в 1961 г. $^{3}$ и доказавшем, что эти же две парадигмы существовали в других индоевропейских языках.

Так родилась новая теория индоевропейского ударения. Главной чертой, отличавшей её от всех прежних теорий, была применимость одного и того же морфонологического принципа ко всей системе в целом (т.е. ко всем частям речи), так что материал, состоящий из крайне разнообразных отдельных фактов, подчинялся небольшому набору весьма простых правил. Все словоформы праязыка теперь стали представимы в виде цепочки морфем с акцентными свойствами («валентностями») одного из двух возможных типов, что исчерпывающе определяет поведение их ударения. Это позволило В. А. Дыбо приступить - впервые в истории языкознания - к реконструкции ц̧елой акцентной системы праязыка (в данном случае праславянского).

Когда были очерчены основные контуры славянской и балтославянской акцентной системы, вся масса накопленных данных - в частности, по глаголам - была подвергнута тщательному анализу для получения подробной классификации засвидетельствованных форм и реконструкции их эволюции. К началу 70-х годов В. А. Дыбо опубликовал большое число отдельных статей, по которым уже тогда можно было составить довольно полное представление о праславянской акцентной системе ${ }^{4}$. Онако различные «ненаучные» обстоятельства препятствовали выходу в свет обобщающей монографии. Наконец, в 1981 г. В. А. Дыбо сумел выпустить «Славянскую акцентологию» та для большинства акцентологов

Параллельно с реконструкцией праславянского ударения, В. А. Дыбо и его ученики изучали балтийскую систему7, в области ударения тесно связанную со славянской, а также связь балтославянского ударения с индоевропейским ${ }^{8}$. Оказалось, что балтославянскую систему можно вообразить почти как некую акцентологическую действительность, с точностью, о какой приходится лишь мечтать в описаниях многих живых языков. Свойственные балтославянской морфеме акцентные типы (каковых было по меньшей мере два), образующие акцентные парадигмы (подвижную и неподвижную) имени и глагола, морфонологические законы словообразования, поведение акцента в синтагме - все эти особенности позволили сделать ряд обобщений, приведших к открытию новой типологической разновидности акцентных систем, дотоле совершенно неизвестной - морофонологизованных парадигматических акцентных систем. Были описаны и проанализированы и другие системы этого типа', находящиеся на разных стадиях эволюции. Это привело к «тонологической гипотезе» их происхождения ${ }^{10}$. Согласно этой гипотезе, возникновению таких систем

этом открытии В. А. Дыбо была уточнена в 1963 г. его другом и сотрудником В. М. Иллич-Свитычем в фундаментальном труде «Именная акцентуация в балтийском и славянском». С тех пор закон, объясняющий происхождение а.п. $b$, известен как «закон Дыбо - Иллич-Свитыча».

${ }^{3}$ Сокращение долгот в кельто-италийских языках и его значение для балто-славянской и индоевропейской акцентологии // Вопросы славянского языкознания. М., 1961. Вып. 5.

${ }^{4}$ Основные работы того времени: Ударение славянского глагола и формы старославянского аориста // Краткие сообщения Института славяноведения АН СССР. М., 1961. № 30. О реконструкции ударения в праславянском глаголе // Вопросы славянского языкознания. М., 1962. Вып. 6. Фрагмент праславянской акцентной системы (Формы-enclinomena в аористе $i$-глаголов) // Советское славяноведение. М., 1968. № 6. Закон Васильева-Долобко и акцентуация форм глагола в древнерусском и среднеболгарском // Вопросы языкознания. М., 1971. № 2. О фразовых модификациях ударения в праславянском // Советское славяноведение. М., 1971. № 6. - И многие другие.

${ }_{5}^{5}$ Славянская акиентология: Опыт реконструкиии системы акцеентных парадигм в праславянском. М., 1981.

6 За это время вышло несколько важных монографий других авторов. Здесь стоит упомянуть две весьма разные работы: KORTLANDT, Frederik. Slavic Accentuation. Lisse, 1975 и GARDE, Paul. Histoire de l'accentuation slave. Paris, 1976, во второй из которых дана реконструкция, основанная главным образом на работах Дыбо (что в сочетании с теоретической ясностью изложения делает эту книгу прекрасным введением в проблематику), тогда как первая исходит из совершенно иных принципов, хотя и принимает во внимания реконструкцию Дыбо (так, «закон Дыбо - Иллич-Свитыча» играет в ней существенную роль).

${ }^{7}$ Например: ДыБо В. А. К вопросу о системе порождения акцентных типов производных имен в прабалтийском // Балтославянские исследования 1980. М., 1981. С. 65-89.

8 ДыБо В. А. Балто-славянская акцентная система с типологической точки зрения и проблема реконструкции индоевропейского акцента. ІІ. Западнокавказские акцентные системы как аналог балто-славянской // Балто-славянские исследования 1987. М., 1989. С. 238-248. НикОЛАЕв С. Л. Балто-славянская акцентуационная система и ее индоевропейские истоки // Историческая акценттология и сравнительно-исторический метод. М., «Наука», 1989. С. 46-109.

9 Западнокавказская акцентная система и проблема ее происхождения // Конференціия. Ностратические языки и ностратическое языкознание. Тезисы докладов. М., 1977. Просодическая система тубу (группа теда-канури) - начало трансформации тональной системы в систему парадигматического акцента? // Африканское историческое языкознание. Проблемы реконструкциии. М., 1987.

${ }^{10}$ Dybo V. A., Nikolayev S. L., Starostin S. A. A Tonological Hypothesis on the origin of paradigmatic accent systems // Estonian papers in phonetics. Tallinn, 1978. 
предшествует состояние, при котором каждая морфема обладает «регистровым тоном». Сочетания разных морфем дают «акцентные кривые», а сами постепенно теряют свой тон, который в итоге проявляется лишь как абстрактный признак, т.н. «валентность». Система эволюционирует дальше к более продвинутым состояниям, при которых ударение становится всё более и более «категориальным», т.е. определяется уже не акцентологическими, а иными факторами.

Таким образом, можно сказать, что сравнительное изучение акцентных систем исторических языков обогатило индоевропейскую реконструкцию, ранее претендовавшую лишь на «сегментный» уровень праформ, новым - «супрасегментным» - аспектом, который индоевропеисты ранее не рассматривали (кроме «очевидных» случаев вроде ступеней чередования корня и т.п.)

Триумфальное шествие сравнительной акцентологии началось с ряда блестящих открытий В. А. Дыбо и продолжается сегодня при участии его многочисленных учеников и сподвижников, занимающихся немалым числом языковых групп с целью обогащения наших представлений о генетическом и типологическом аспектах акцентологической эволюции языка.

Другая область знания, чьё выживание было бы под вопросом, если бы не усилия Владимира Антоновича, - это ностратическое языкознание. В. М. Иллич-Свитыч, отец современной ностратики, проделал грандиозную работу по сбору данных из сотен языков для создания ностратической реконструкции и словаря. После трагической кончины Иллич-Свитыча в 1966 г., помешавшей ему завершить дело своей жизни, В. А. Дыбо взял на себя труднейшую задачу осуществить великий замысел друга. Результат - выход в свет (в 1971, 1976 и 1984 гг.) трёх томов словаря под редакцией В. А. Дыбо1, который существенно доработал и расширил материал и теорию Иллич-Свитыча. Благодаря этому обстоятельству ностратическое языкознание стало плодотворной и строгой отраслью, объединившей немало специалистов мирового масштаба. ${ }^{12}$

Количество замыслов, которые успел осуществить В. А. Дыбо на протяжении своего научного пути весьма внушительно. Не менее внушительна их широта, для большинства «обычных лингвистов» невообразимая. Но Владимир Антонович и не думает останавливаться на достигнутом. На вопрос, заданный ему на дне рождения: «А что бы вы сами себе пожелали?», именинник ответил: «Желаю себе наконец начать акцентологическую реконструкцию ностратического». А потом добавил: «Конечно, сперва закончив индоарийскую.» Значит, нам, ученикам и почитателям таланта Владимира Антоновича, нечего волноваться: триумфальное шествие продолжается.

С днём рождения, Владимир Антонович!

М. Ослон и редакцичя журнала

\section{A l'occasion du 80 ${ }^{\text {ème }}$ anniversaire de Vladimir Antonovitch Dybo (30 avril 2011)}

Trois conférences linguistiques ont déjà eu lieu cette année à Moscou en l'honneur de l'anniversaire du Prof. Dybo, anniversaire qui, outre sa signification chronologique - puisqu'il marque plus d'un demi-siècle d'activité scientifique brillante du grand linguiste, - présente une excellente occasion d'évaluer l'ampleur extraordinaire de ses intérêts scientifiques. Les collègues et les élèves de Vladimir Antonovitch ont, dans leurs exposés, touché à une grande variété de sujets, tels que l'accentologie balto-slave, indoeuropéenne et ouralique, la glottochronologie, la turcologie et la caucasologie comparées, aussi bien que d'autres domaines qui intéressent le Prof. Dybo et dans la plupart desquels s'est manifesté son génie de comparatiste. Les exposés offerts au cours de ces conférences jubilaires ont encore une fois démontré le rôle du Prof. Dybo dans ces domaines, qui n'auraient sûrement pas atteint leur niveau actuel sans sa participation active et déterminante.

${ }^{11}$ Илдич-Свитыч В. М. Опыт сравнения ностратических языков: Сравнительный словарь. В 3 тт. / Под ред. В. А. ДыБО. М.: Наука, 1971, 1976, 1984.

12 Таких как, например, крупнейший русский языковед С. А. Старостин, тоже, увы, скоропостижно скончавшийся (в 2005 г.). 